\title{
DÜŞÜK BROMÜR VE ORGANİK MADDE İÇEREN SU KAYNAKLARI İÇIN ÖN DEZENFEKTAN SEÇİMINDE ÇOK ÖLÇÜTLÜ KARAR VERME METOTLARININ UYGULANMASI
}

Cihan $\ddot{O Z Z G \ddot{R}}$

Alınma: 30.05.2020; düzeltme: 11.07.2020; kabul: 06.08.2020

Öz: Birçok iyi ya da birçok kötü seçenek arasından karar verme, yöneticilerin ve idarecilerin en fazla zorlandıkları durumların başında gelmektedir. İçme suyu kaynaklarında kullanılmak üzere seçilecek ön dezenfektan türleri de oldukça fazladır ve bu durum seçimi güçleştirmektedir. Bu çalışmada ülkemizin su kaynaklarının genel durumu göz önüne alınarak düşük organik madde ve düşük bromür konsantrasyonuna sahip su kaynakları için ön dezenfektan seçiminde karar almayı kolaylaştırmak adına "Çok Ölçütlü Karar Verme Yöntemleri” Kullanılmıştır. Çalışma kapsamında “Analitik Hiyerarşi Süreci” (AHS) ve "Technique for Order Preference by Similarity to Ideal Solution" (TOPSIS) tekniklerinin kombinasyonundan oluşan bir analiz metodu kullanılmıştır. Bu kapsamda 6 kriter (Bakiye Dayanıklılık-Mikroorganizma GiderimiTeçhizat Gereksinimi-Güvenlik Endişeleri-pH Bağımlılığı-Sağlık Etkileri) ve 6 alt kriter (Klor (Gaz)-Klor (Sıv1)-Ozon-Klor Dioksit-Kloramin-UV) belirlenerek, uzman görüşleri ve literatür bilgisinden yararlanılarak sistematik bir çalışma gerçekleştirilmiştir. Bakiye dayanıklılığın yüksek olması, teçhizat gereksiniminin yüksek olmaması, $\mathrm{pH}$ bağımlılığının yüksek olmaması ve nispeten düşük sağlık endişeleri gibi avantajlarından dolayı klor gazı en iyi ön dezenfektan olarak tespit edilirken UV ise en son tercih edilmesi gereken dezenfektan olarak belirlenmiş̧ir.

Anahtar Kelimeler: AHS, Çok Ölçütlü Karar Verme Metotları, Dezenfeksiyon, İçme Suyu Arıtımı, TOPSIS

\section{Implementation of Multi-Criteria Decision Making Methods for Pre-Disinfectant Selection for Water Resources Containing Low Bromide and Organic Matter}

\begin{abstract}
Deciding among many good or bad options is one of the most difficult situations for managers and administrators. The types of pre-disinfectants to be selected for use in drinking water resources are also quite high and this makes the choice difficult. In this study, "Multi Criteria Decision Making Methods" were used in order to facilitate decision making for the selection of pre-disinfectants for water sources with low organic matter and low bromide concentration considering the general condition of our country's water resources. An analysis method consisting of the combination of "Analytic Hierarchy Process" (AHP) and "Technique for Order Preference by Similarity to Ideal Solution" (TOPSIS) techniques was used in the study. In this context, a systematic study was carried out by determining 6 criteria (Residual DisinfectantMicroorganism Removal-Equipment Requirement-Security Concerns-pH Dependence-Health Effects) and 6 sub-criteria (Chlorine (Gases)-Chlorine (liquid)-Ozone-Chlorine Dioxide-Chloramine-UV) and making use of expert opinions and literature knowledge. Due to the advantages such as high residual resistance, low equipment requirement, low $\mathrm{pH}$ dependency and relatively low health concerns, chlorine gas is determined as the best pre-disinfectant, while UV is the last disinfectant to be preferred.
\end{abstract}

Keywords: AHP, Disinfection, Drinking Water Treatment, Multi-Criteria Decision Making, TOPSIS

\footnotetext{
* Isparta Uygulamalı Bilimler Üniversitesi, Sütçüler Prof. Dr. Hasan Gürbüz Meslek Yüksekokulu, 32950, Isparta, Türkiye
} 
Özgür C.: Düşük Bromür ve Orgn. Madde İçer. Su Kayn. İçin Ön Dezenf. Seçim. Çok Ölç. Karar Metotlar.

\section{GİRİ̧}

Gelişen bilim ve teknoloji birçok yeni fikrin türetilmesine ve uygulanmasına olanak sağlamaktadır. Yeni fikirlerin ortaya çıkışı ile birlikte doğal süreç içerisinde eski ve yeni fikirlerin kıyaslanması da kaçınılmazdır. Bu konuda kişiler karar verme bilinmezi ile karşı karşıya kalmaktadır. Karar verme bir amacı gerçekleştirmek için eldeki imkanları göz önüne alarak en uygun durumu belirlemektir. Karar verme aşamasında deneyim, sezgi ve akıl çok önemli olsa da her zaman en iyi alternatifin belirlenmesinde yeterli olmamaktadır. Çok Ölçütlü Karar Verme metotları bu zorlu sürecin hafifletilmesinde karar vericilere kolaylıklar tanımaktadır.

Çok Ölçütlü Karar Verme metotları aynı amaca yönelik hedeflerin, karar vericilerin karşılaştığı belirsiz, karmaşık ve çelişkili durumları gözler önüne sererek daha iyi karar verilmesini sağlayan süreçler bütünüdür (Ömürbek ve diğ., 2014). Karar verme, problemlerin çözümünde matematiksel modeller, sayısal ifadeler ve istatistiksel teknikler kullanılarak en iyi alternatifin belirlenmesinde kullanılan bir yöntem olarak uygulanmaktadır (Atıcı ve Ulucan, 2009). Genellikle işletmeciler tarafından kullanılan çok kriterli karar verme yöntemleri (Elimination Et Choice Translating Reality (ELECTRE), Technique for Order Preference by Similarity to Ideal Soluiton (TOPSIS), Vise Kriterijumska Optimizacija I Kompromisno Resenje (VIKOR), Multi Attribute Utility Theory (MAUT), Complex Proportional Assessment (COPRAS), Utilités Additives (UTA), Measuring Attractiveness by a Categorical Based Evaluation Technique (MACBETH), Preference Ranking Organization Method for Enrichment Evaluations (PROMETHEE), Multi-Objective Optimization on Basis of Ratio Analysis (MOORA) vd.) günümüzde yaygınlaşarak birçok alanda da kullanılmaya başlanılmıştır (Özcan ve Ömürbek, 2020). Çevre Mühendisliği alanında da Çok Ölçütlü Karar Verme uygulamaları son y1llarda artan bir trend göstermektedir (Simonovic ve Verma, 2008; Chung ve Lee, 2009; Okeola ve Sule, 2012; Tobiszewski ve Orłowski, 2015; Yan ve diğ., 2016; Chowdhury, 2017; Karahalios, 2017; Öztürk, 2017; Butchart-Kuhlmann ve diğ., 2018; Öztürk, 2018; Jones ve diğ., 2019).

Morais ve Almeida (2006) çalışmalarında su temin edilen şehirlerin öncelik sırasını belirlemek için ELECTRE metodunu uygulamışlardır. Negi ve Jain (2008) gerçekleştirdikleri çalışmada Analitik Hiyerarşi Sürecini (AHS) kullanarak yeraltı sularının yoğun olduğu bölgelerde hangi endüstriyel faaliyetlerin uygulanmaması gerektiğini tespit ederek, ağır metal sektörünün uygun olmadığını belirlemişlerdir. Bouchard ve diğ., (2010) küçük su arıtma tesisleri için uygun arıtma sürecinin belirlenmesinde halk sağlığı, maliyet, sistem gereksinimleri ve uygulama zorluğu kriterlerini kullanarak ELECTRE II metodunu uygulamışlardır. Sudhakaran ve diğ., (2013) çalışmalarında su kaynaklarından organik mikrokirleticilerin gideriminde en uygun arıtma yönteminin belirlenmesinde Çok Ölçütlü Karar Verme metotlarını kullanmışlardır. Esquivel ve diğ., (2015) Çok Ölçütlü Karar Verme yöntemlerinden biri olan AHS'yi kullanarak yeraltı sularının izlemesini gerçekleştirmişlerdir. Santos ve diğ., (2016) güneş ışığı dezenfeksiyonu, suyun kaynatılmas1, klorlama, kimyasal arıtma + dezenfeksiyon, filtrasyon ve biyo-kum filtrasyonu tekniklerini kıyaslamak için AHS ve TOPSIS metotlarını kullanmışlardır. Öztürk (2018) triclosanı su ve atıksudan uzaklaştırmak için en iyi yöntemi belirlerken AHS metodunun akabinde TOPSIS, VIKOR ve PROMETHEE yöntemlerini kullanmıştır.

Türkiye su kaynakları bakımından coğrafi olarak oldukça zengin gözükse de nüfus açısından bakıldığında, kişi başına düşen su miktarı 2020 yılı itibari ile $1346 \mathrm{~m}^{3} / \mathrm{y} 1 \mathrm{l}$ olduğu için su azlığ yaşayan bir ülkedir ve 2030 yılında kişi başına düşen su miktarının $1120 \mathrm{~m}^{3} / \mathrm{y}$ ll olacağ 1 tahmin edilmektedir (DSİ, 2020). Ancak su kaynaklarının ülke genelinde düşük organik madde (toplam organik karbon (TOK)) ve düşük bromür içeriğinden dolayı yüksek kaliteli su sınıfında olduğu söylenebilir (Ateş ve diğ., 2007). "İnsani Tüketim Amaçlı Sular Hakkında Yönetmelik" kapsamında TOK sadece gösterge parametre olarak yer almaktadır. Ancak günümüzde bazı ülkelerde (örn. Amerika) TOK parametresinin $2 \mathrm{mg} / \mathrm{L}$ 'nin altında olması istenmektedir (Wallace ve diğ., 2002). Ayrıca su kaynaklarındaki bromür konsantrasyonu 0,1 mg/L'nin üzerinde ise yüksek konsantrasyon olarak kabul edilir (USEPA, 1999). Su kaynaklarının TOK içeriği, 
dezenfeksiyon ünitelerinde kullanılan dezenfektanlar ile tepkime sonucu oluşabilecek sitotoksik ve karsinojenik dezenfeksiyon yan ürünlerinin (DYÜ) oluşumunda oldukça önemlidir (Rook, 1974). DYÜ oluşumunu kontrol etmenin ve azaltmanın temel mekanizmaları ya sulardaki organik madde konsantrasyonunu azaltmak ya da kullanılan dezenfektan konsantrasyonunu azaltmaktır. Organik madde konsantrasyonunu azaltmak için uygulanacak prosesler işletme maliyetlerini arttıracağından dolayı işletmeciler tarafından kullanılan dezenfektan miktarını azaltma yoluna gidilmektedir. Bu amaçla ön dezenfektan kullanımı oldukça önemlidir. Ön dezenfektan prosesi içme suyu arıtma tesislerinin girişinde uygulanarak hem tesis için bir yük oluşturan organik madde konsantrasyonunun azalmasına hem de son dezenfektan olarak kullanılacak klorun daha düşük konsantrasyonda kullanılmasına zemin hazırlayacaktır. Su arıtma tesislerinde kolay kullanım, bakiye bırakma ve maliyet gibi avantajlarından dolayı en yaygın kullanılan son dezenfektan klordur (Kumari ve Gupta, 2015). Ancak klor kullanımına bağlı olarak sularda trihalometan (THM) ve haloasetik asit (HAA) gibi karbonlu DYÜ türlerinin artması; kloramin, ozon, klor dioksit, UV gibi alternatif dezenfektanların kullanımına yönelime neden olmuştur (Voukkali ve Zorpas, 2015). Sularda dezenfektan olarak kloramin kullanımı karbonlu DYÜ türlerine kıyasla çok daha sitotoksik ve genotoksik olduğu bilinen azotlu DYÜ türlerinin oluşumuna neden olmaktadır (Gan ve diğ., 2013). Ozon kullanımı ise sularda bromür varlığında genotoksik kanserojen yan ürün olan bromat oluşumunu desteklediğinden ve bakiye bırakmama özelliği gibi dezavantajlar sunmaktadır (Cortes ve Marcos, 2018). Klordioksit kullanımı da Amerika'da mevzuatlar tarafindan üst limitler getirilen klorit ve klorat oluşumuna neden olmaktadır (Ersan ve diğ., 2019). UV hem bakiye bırakmama özelliği hem de teçhizat gereksinimi ihtiyacından dolayı ilk tercih edilen dezenfektan olmamaktadır (Song ve diğ., 2016). Tüm dezenfektanların olumlu yönleri olduğu gibi özellikle halk sağlığı açısından, maliyet bakımından ve güvenlik endişeleri bakımından birçok olumsuz senaryo söz konusudur ve karar vermek oldukça zordur.

$\mathrm{Bu}$ çalışmanın amacı özellikle ülkemizde bulunan su kaynaklarının düşük TOK ve düşük bromür konsantrasyonları göz önüne alınarak, Çok Ölçütlü Karar Verme yöntemlerini kullanarak içme suyu arıtma tesisleri için en uygun ön dezenfektan türünü belirlemektir. Ülkemizde mevzuatlar gereği son dezenfektan olarak bakiye bırakma özelliği olan klor kullanımı zorunludur. Ancak ön dezenfektan tercihinde bir zorunluluk söz konusu değildir. İçme suyu arıtma tesislerinde ön dezenfektan olarak farklı oksidanlar kullanılabilir. Bu yüzden çalışma kapsamında düşük TOK ve düşük bromür içeren su kaynakları için en ideal ön dezenfektan belirleme çalışması gerçekleştirilmiştir.

Çalışma kapsamında ilk olarak kriterlere göre alternatiflerin aldıkları ağırlık puanları AHS tekniği ile belirlenmiştir. AHS tekniğinde kriterler "Bakiye Dayanıklılık", "Mikroorganizma Giderimi”, "Teçhizat Gereksinimi”, "Güvenlik Endişeleri”, "pH Bağımlılığı” ve "Sağlık Etkileri” olarak belirlenmiştir. Alt kriterler (alternatifler) ise "Klor (gaz)", "Klor (sıv1)", "Ozon", "Klor Dioksit", "Kloramin" ve "UV"'dir. AHS ile elde edilen kriterlere göre alternatiflerin aldıklar1 ağırlıklı puanlar TOPSIS tekniği ile değerlendirilerek düşük organik madde ve düşük bromür konsantrasyonuna sahip su kaynakları için en iyi ön dezenfektan türünün belirlenmesi amaçlanmıştır. Bu çalışmanın ülkemizde ve ülkemize benzer şekilde düşük TOK ve düşük bromür içeren su kaynakları ile çalışan karar vericilere, mühendislere, operatörlere aynı zamanda Çok Ölçütlü Karar Verme teknikleri üzerine araştırmalar yapmak isteyen akademisyenlere katk1 sağlayacağı ön görülmektedir.

\section{YÖNTEM}

\subsection{Analitik Hiyerarşi Süreci}

Düşük TOK ve düşük bromür içeren su kaynakları için en iyi ön dezenfektan türünün belirlenmesini amaçlayan bu çalışmada sistematik bir süreç yürütülmüştür. Bu süreçte 6 farklı kriter ve 6 farklı alt kriter belirlenmiştir. Alt kriterlerin ya da bir başka deyişle alternatiflerin 
kriterlere göre ağırlıklarının belirlenmesinde AHS tekniği kullanılmıştır. AHS 1970’li yıllarda Thomas L. Saaty tarafından literatüre kazandırılmış bir yöntemdir (Bertolini ve Bevilacqua, 2006). AHS'de temel olarak (i) hiyerarşi kurulur (ii) alternatiflerin birbirlerine göre üstünlükleri belirlenir ve (iii) sayısal olarak puanlanarak üç aşamada gerçekleştirilir (Ömürbek ve diğ., 2014). Hiyerarşi kurulurken en üstte amaç olmalıdır. Çalışmanın amacı "Ön Dezenfektan Seçimi”" olarak belirlenmiş̧ir. Bir alt kademede karar verme kalitesinin belirlenmesinde görev alan kriterler yer almalıdır. En alt seviyede ise alternatifler yer almalıdır. Hiyerarşi oluşturulduktan sonra, Tablo 1 'de gösterilen ikili karşılaştırmada kullanılan önem dereceleri tablosu oluşturulmalıdır. Wind ve Saaty (1980) tarafından öne sürülen bu tabloda her bir kriter için alternatifler ikili eşleşmeler halinde puanlandırılmalıdır. Örneğin bu çalışmada bakiye dayanıklılık kriteri değerlendirildiğinde ilk olarak klor (gaz) ve klor (sıvı) kıyaslanmış ve daha sonra tüm alternatiflerin kıyaslanması kendi aralarında tekrarlanmıştır. Karar matrisinde "1" önem derecesi alternatifin kendisi ile kıyaslanmasında kullanılmalıdır. Her iki alternatif kıyaslanırken birbirleri üzerindeki önem derecesi oldukça önemlidir. AHS yönteminin uygulama aşamaları ve kullanılan formüller Özbek (2017) ve Yıldırım ve Önder (2018)'e göre oluşturulmuştur.

Tablo 1. İkili karşılaştırmada kullanılan önem dereceleri tablosu (Wind ve Saaty, 1980)

\begin{tabular}{|c|l|l|}
\hline $\begin{array}{c}\text { Önem } \\
\text { Derecesi }\end{array}$ & Tanım & Açıklama \\
\hline 1 & Eşit Derecede Önemli & Her iki faktör aynı öneme sahiptir. \\
\hline 3 & Orta Derecede Önemli & $\begin{array}{l}\text { Tecrübe ve yargılara göre bir faktör diğerine göre biraz daha } \\
\text { önemlidir. }\end{array}$ \\
\hline 5 & Kuvvetli Derecede Önemli & Bir faktör diğerinden kuvvetle daha önemlidir. \\
\hline 7 & Çok Kuvvetli Derecede Önemli & $\begin{array}{l}\text { Bir faktör diğerine göre yüksek derecede kuvvetle daha } \\
\text { önemlidir. }\end{array}$ \\
\hline 9 & Mutlak Derecede Önemli & $\begin{array}{l}\text { Faktörlerden biri diğerine göre çok yüksek derecede } \\
\text { önemlidir. }\end{array}$ \\
\hline $2,4,6,8$ & Ara Değerler & $\begin{array}{l}\text { İki faktör arasındaki tercihte yukarıdaki açılamalarda } \\
\text { bulunan derecelerin ara değerleridir. }\end{array}$ \\
\hline
\end{tabular}

\subsection{TOPSIS}

Çalışma kapsamında TOPSIS tekniği alternatiflerin bir dizi işlem sonrası kazandıkları ağırlık puanlarının sıralanması amacıyla kullanılmıştır. TOPSIS yöntemi ilk kez Hwang ve Yoon (1981) tarafindan öne sürülmüş bir teknik olup Chen ve Hwang (1992) tarafından geliştirilmiştir (Demireli, 2010). Basit, kolay anlaşılır olması ve sınırlı sayıda girdi gereksinimi olmasından dolayı TOPSIS yöntemi karar vericiler tarafından sıklıkla kullanılmaktadır (Yeh, 2002). Yöntem temel olarak basit matematiksel denklemler üzerinden her bir alternatifin performansinı değerlendirmektedir (Ömürbek ve diğ., 2014). Yapılan çalışmada kriterlerin ağırlık puanları TOPSIS yönteminde kullanılmak üzere AHS metodu ile oluşturulmuştur. TOPSIS metodunun uygulama aşamaları Özbek (2017) ve Yıldırım ve Önder (2018)'e göre şekillendirilmiştir.

\section{BULGULAR VE TARTIŞMA}

Çalışmada düşük TOK ve düşük bromür konsantrasyonuna sahip su kaynaklarında en uygun ön dezenfektan türünü belirlemek üzere sırasıyla AHS ve TOPSIS yöntemleri kullanılmıştır. Çalışmanın amacına uygun hiyerarşik yapı, Şekil 1'de gösterilmektedir. Çalışmanın ana amacı ön dezenfektan seçiminde Çok Ölçütlü Karar Verme yöntemlerinin uygulanabilirliğidir. Kriterler uzman görüşleri doğrultusunda belirlenmiştir. Ayrıca alternatifler olarak belirlenen dezenfektanlar da seçme eleme kriterleri neticesinde belirlenmiştir. Su kaynaklarına filtrasyon işlemi sonrası uygun ön dezenfektan seçiminde uzmanlar tarafından sorulan ilk soru TOK 
konsantrasyonun değeridir. Akabinde sorulan bir diğer soru ise bromür konsantrasyonudur. Ĕger hem yüksek TOK hem de yüksek bromür konsantrasyonuna sahip bir su kaynağı ise uygulanması gereken ön dezenfektan klor dioksit veya UV'dir (Richardson ve diğ., 2003; Ignatev ve Tuhkanen, 2019). Eğer yüksek TOK ancak düşük bromür konsantrasyonuna sahip bir su kaynağ ise yüksek DYÜ oluşum potansiyelinin oluşacağı da göz önüne alınarak ozon, klor dioksit veya UV kullanılabilir (Neale ve Leusch, 2019). Eğer su kaynağı düşük TOK ancak yüksek bromür konsantrasyonuna sahip ise klor dioksit, klor veya UV kullanılabilir (Neale ve Leusch, 2019). Eğer bu çalışma kapsamında olduğu gibi su kaynağı düşük TOK ve düşük bromür konsantrasyonuna sahip ise klor dioksit, klor, ozon, UV ya da bu dezenfektanların kombinasyonları kullanılabilir (Toröz, 2015). Tüm bu sebeplerden dolayı alternatifler gaz ve sıv1 klor, kloramin, klor dioksit ve UV olarak seçilmiştir. Ancak hangi dezenfektan ön dezenfektan olarak seçilirse seçilsin "İnsani Tüketim Amaçlı Sular Hakkında Yönetmelik" uyarınca dağıtım şebekesinde en uzak noktada $0,5 \mathrm{mg} / \mathrm{L}$ serbest bakiye klor konsantrasyonu sağlamak zorunlu olduğundan az da olsa klor son dezenfektan olarak kullanılmalıdır (ITASHY, 2005). Uzman görüşlerinin alınması ve literatür kaynaklarının incelenmesi neticesinde seçilen kriterler ile ilgili aşağıdaki bilgiler tespit edilmiştir.

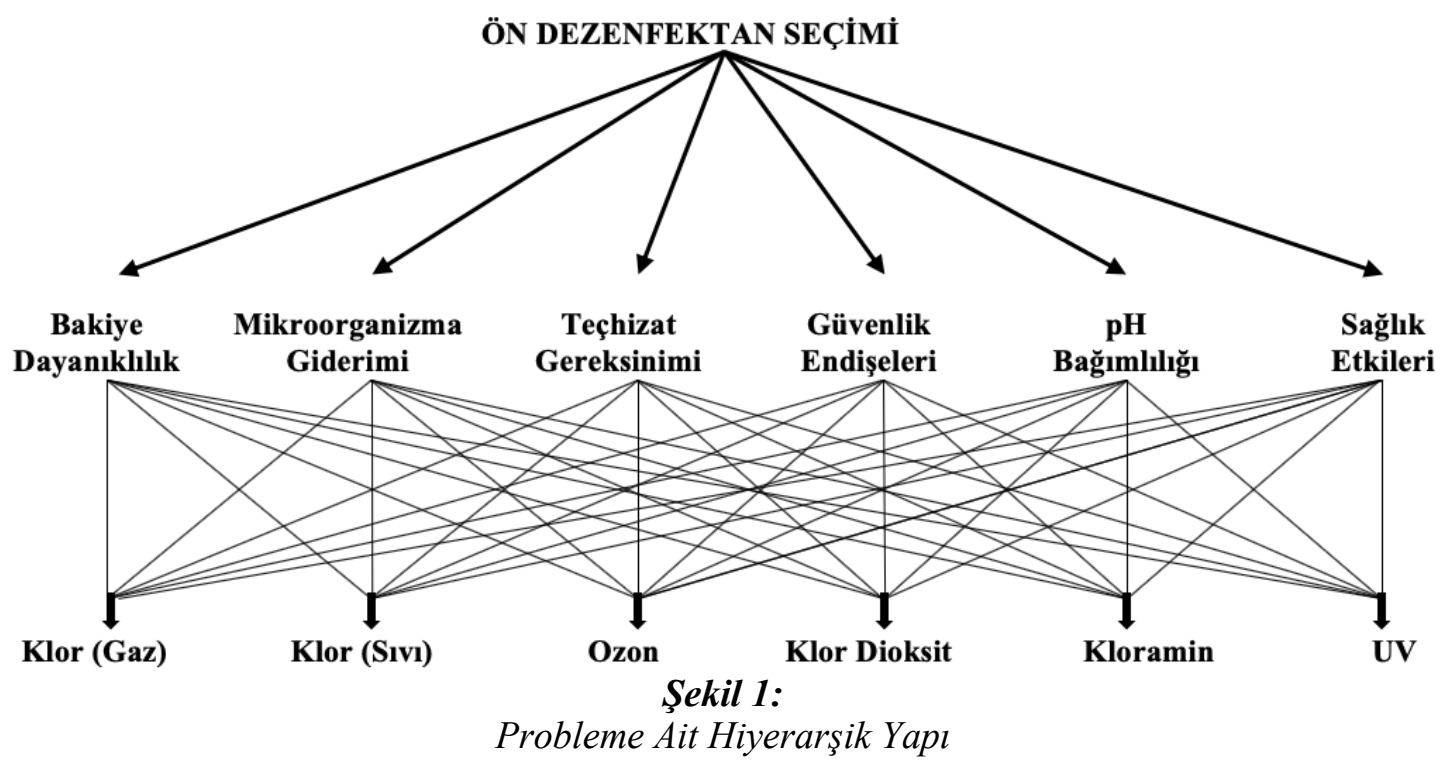

Bakiye Dayanıklılık: Alternatifler değerlendirildiğinde ozon ve UV'nin bakiye bırakma özelliğinin olmadığı görülmektedir (Summerfelt, 2003). Kloramin, gaz ve sıvı klor formları ile kıyaslandığında daha düşük bakiye bırakma özelliğine sahiptir (Lin ve diğ., 2018). Klor dioksitin tüm alternatifler arasında en yüksek bakiye bırakma özelliğine sahip olduğu tespit edilmiştir (Aieta ve Berg, 1986).

Mikroorganizma Giderimi: Gaz ve sıvı klor uygulamalarında bakteride solunum, taşınım ve nükleik asit aktivitelerinin tamamı olumsuz etkilenir (Ridgway ve Olson, 1982). Klor dioksit protein sentezinin yok edilmesinde önemli etkene sahiptir (Huang ve di $\breve{g} ., 1996$ ). UV ise 200-300 nm arasında 1şı̆̆ absorblar ve nükleik asitlerde spesifik zarara neden olur (Chang ve diğ., 1985). Ozonun bakteriler üzerindeki inaktivasyon mekanizması UV'e benzer şekildedir.

Teçhizat Gereksinimi: Alternatifler arasında en yüksek teçhizat gereksinimine ozon ihtiyaç duymaktadır. Ozon yerinde üretilmelidir ve çok hızlı bir şekilde kararsız yapıya ulaştığı için ivedilikle tatbik edilmelidir (Oğuzhan Yıldız ve Yangılar, 2014). Ozon üretimi için yüksek elektrik talebi vardır. Klor (gaz), klor dioksit, kloramin ve UV sistemleri için de benzer zorlukta ekipmanlara ihtiyaç duyulmaktadır. Klor (gaz) için bir kaçak önleme sistemine ihtiyaç vardır. 
Özgür C.: Düşük Bromür ve Orgn. Madde İçer. Su Kayn. İçin Ön Dezenf. Seçim. Çok Ölç. Karar Metotlar.

Kloramin üretiminde kullanılan amonyak için ilave makine-teçhizat gereksinimi duyulmaktadır. Tüm alternatifler arasında klor (sıvı) en az teçhizat gereksinimi olan dezenfektandır.

Güvenlik Endişeleri: Klor (gaz) uygun şartlarda depolanmadığında ya da kullanılmadığında oldukça patlayıcı bir dezenfektandır (Emetere ve Akinyemi, 2017). Aynı şekilde saf klor dioksit patlayıcıdır (Dong ve diğ., 2017). Ozon \%23'ten büyük konsantrasyonlarda patlayıcı özellik göstermektedir (Brodowska ve diğ., 2018). Kloramin hazırlanmasında kullanılan amonyak nedeniyle sizıntılardan dolayı tehlikeli hale gelmektedir. UV dezenfeksiyonunda kullanılan lambalardan dolayı operatörler için tehlikelidir.

pH Băğımlılı̆ğ: Gaz ve sıvı klor ayrıca kloramin, farklı $\mathrm{pH}$ değerindeki su kaynaklarında oldukça değişken özellik gösterir. Klor suya eklendiğinde $\mathrm{pH} 7.8$ ve üstünde hipoklorit iyonları baskınken, $\mathrm{pH}$ 4.0-6.0 arasında hipokloröz asit hakimiyeti söz konusudur. Kloramin oluşumu için de yüksek pH seviyeleri gerekmektedir (Özgür, 2019).

Săglık Etkileri: Klor, doğal organik maddeler (DOM) ile tepkime vererek başta THM ve HAA olmak üzere karbonlu DYÜ türlerinin oluşumundan sorumludur (Rook, 1974). Kloraminler de DOM'lar ile tepkime vererek azotlu DYÜ türlerinin oluşmasına sebep olurlar (Bond ve diğ., 2015). Azotlu DYÜ'ler karbonlu DYÜ'lere kıyasla çok daha düşük konsantrasyonda olmasına rağmen çok daha sitotoksik, genotoksik ve karsinojeniktir (Xue ve diğ., 2014). Klor dioksit su arıtma koşulları altında klorite dönüşür (Ersan ve diğ., 2019). Sularda bromür olması durumunda ise ozon bromür ile tepkime vererek bromlu DYÜ türlerini oluşturur (Hao ve diğ., 2017). UV ile DYÜ türleri arasında ise herhangi bir oluşum henüz tespit edilememiştir (Ao ve diğ., 2020).

\subsection{Analitik Hiyerarşi Süreci Bulguları}

Çalışmanın ilk aşaması AHS'dir. AHS uygulanırken her bir kriter için alternatifler ikili olarak gruplanıp, Tablo 1'deki sisteme göre puanlanmaktadır. Burada alternatiflerin puanlamasında uzman görüşleri dikkate alınmış ve alınan geri dönüşler sayısallaştırıldıktan sonra aritmetik ortalamaya göre puanlar belirlenmiştir. AHS hesaplamaları Microsoft Excel hesap programı ile gerçekleştirilmiştir.

AHS tekniği uygulanırken ilk olarak bir $A$ matrisi oluşturulmalıdır. $A$ matrisinde i matrisin satırını, j ise matrisin sütununu göstermektedir. $A$ matrisi, Denklem 1'de gösterilmektedir.

$$
A=\left[\begin{array}{ccc}
a_{11} & \cdots & a_{1 n} \\
\vdots & \ddots & \vdots \\
a_{n 1} & \cdots & a_{n n}
\end{array}\right], a_{i j}=1 / a_{i j}
$$

Burada $a_{i j} \neq 0$ olmalı. Bu matris elde edildikten sonra bir $B$ matrisi oluşturulmalıdır. $\mathrm{Bu} B$ matrisinin amacı tüm değerleri aynı aralık içine alarak normalize edilmiş değerlerin oluşturulmasıdır. Normalize etmek için kullanılan formül, Denklem 2'de ve normalize edilmiş $B$ matrisi, Denklem 3'te gösterilmektedir.

$$
\begin{gathered}
b_{i j}=\frac{a_{i j}}{\sum_{i=j}^{n} a_{i j}} \\
B=\left[\begin{array}{ccc}
b_{11} & \cdots & b_{1 n} \\
\vdots & \ddots & \vdots \\
b_{n 1} & \cdots & b_{n n}
\end{array}\right]
\end{gathered}
$$


Daha sonra normalize edilmiş tüm kriterlerin ağırlıklarının toplamının kriter sayısına bölünmesi ile her bir kritere göre alternatiflerin puanları hesaplanmaktadır ve Denklem 4'te formül, Denklem 5'de oluşan son matris gösterilmektedir.

$$
\begin{gathered}
w_{i}=\frac{\sum_{i=j}^{n} b_{i j}}{n} \\
W=\left[w_{i}\right]_{n x 1}=\left[\begin{array}{c}
w_{1} \\
: \\
w_{n}
\end{array}\right]
\end{gathered}
$$

Kriterlerin ağırlık vektörü $C$, alternatiflerin kriter puanları matrisi $S$ ile gösterilirse $C$ vektörü ile $S$ matrisinin transpozunun çarpımı ile alternatiflerin genel puanı hesaplanmış olur (Denklem $6)$.

$$
\begin{gathered}
P=C * S=\left[w_{i}\right]_{n x 1} *\left[w_{i j}\right]_{n x n} \\
P=\left[P_{i}\right]_{1 x n}
\end{gathered}
$$

Alternatiflerin genel puanını gösteren $P$ vektöründe, alternatiflerin sıralaması genel puanı en büyük olandan başlamak üzere yapılır. Son olarak AHS tekniğinde sübjektif olan algıların tutarlılığını ve göreli ağırlıkların doğruluğunu sağlamak amacıyla Tutarlılık Oranı $(C R)$ ve Tutarlılık İndeksi (CI) katsayıları kullanılmaktadır. Tutarlılık indeksi

$$
C I=\frac{\lambda_{\text {maks }}-n}{n-1}
$$

formülü ile hesaplanmaktadır. Burada $\lambda_{\text {maks }}$, vektörün en büyük özdeğeridir ve $\mathrm{n}$ ise toplam kriter sayısıdır. Sonuçların daha güvenilir olabilmesi için tutarlılık indeksi 0,1'den büyük olmamalıdır. Tutarlılık oranı için ise;

$$
C R=\frac{C I}{R I}
$$

eşitliği kullanılır. Burada RI "Rastgele Değer İndeksi"ni göstermektedir. Tutarlılık göstergeleri 1-10 boyutlu matrisler için, Tablo 2'deki gibidir.

Tablo 2. Rastgele Değer İndeksleri

\begin{tabular}{|c|c|c|c|c|c|c|c|c|c|c|}
\hline Kriter Sayı11 (N) & 1 & 2 & 3 & 4 & 5 & 6 & 7 & 8 & 9 & 10 \\
\hline $\begin{array}{c}\text { Rastgele Değer } \\
\text { İndeksi (RI) }\end{array}$ & 0,00 & 0,00 & 0,58 & 0,90 & 1,12 & 1,24 & 1,32 & 1,41 & 1,45 & 1,49 \\
\hline
\end{tabular}

Çalışma sonuçlarına göre "Bakiye Dayanıkl1lık" için CI=0,08, "Mikroorganizma Giderimi" için $\mathrm{CI}=0,09$, "Teçhizat Gereksinimi" için $\mathrm{CI}=0,08$, "Güvenlik Endişeleri" için $\mathrm{CI}=0,06$, , $\mathrm{pH}$ Bağımlılığı" için $C I=0,08$, "Sağl1k Etkileri”" için $C I=0,07$ olarak belirlenmiştir. AHS yöntemi ile 
Özgür C.: Düşük Bromür ve Orgn. Madde İçer. Su Kayn. İçin Ön Dezenf. Seçim. Çok Ölç. Karar Metotlar.

kriterlerin alternatiflere göre ağırlıkları, Tablo 3'te ve kriterler ve alternatifler arasındaki ilişki ise, Şekil 2'de gösterilmektedir.

Tablo 3. Kriterlere Göre Alternatiflerin Ağırlıkları

\begin{tabular}{|c|c|c|c|c|c|c|}
\hline & $\begin{array}{c}\text { Klor } \\
(\text { Gaz })\end{array}$ & $\begin{array}{c}\text { Klor } \\
(\text { Siv1 })\end{array}$ & Ozon & $\begin{array}{c}\text { Klor } \\
\text { Dioksit }\end{array}$ & Kloramin & UV \\
\hline Bakiye Dayanıklılık & 0,16 & 0,16 & 0,04 & 0,54 & 0,08 & 0,03 \\
\hline $\begin{array}{c}\text { Mikroorganizma } \\
\text { Giderimi }\end{array}$ & 0,08 & 0,04 & 0,21 & 0,14 & 0,03 & 0,49 \\
\hline Teçhizat Gereksinimi & 0,08 & 0,03 & 0,44 & 0,25 & 0,04 & 0,16 \\
\hline Güvenlik Endişeleri & 0,26 & 0,05 & 0,15 & 0,45 & 0,03 & 0,07 \\
\hline pH Bağlılığı & 0,15 & 0,25 & 0,08 & 0,04 & 0,45 & 0,03 \\
\hline Sağlık Etkileri & 0,15 & 0,15 & 0,04 & 0,54 & 0,08 & 0,03 \\
\hline
\end{tabular}

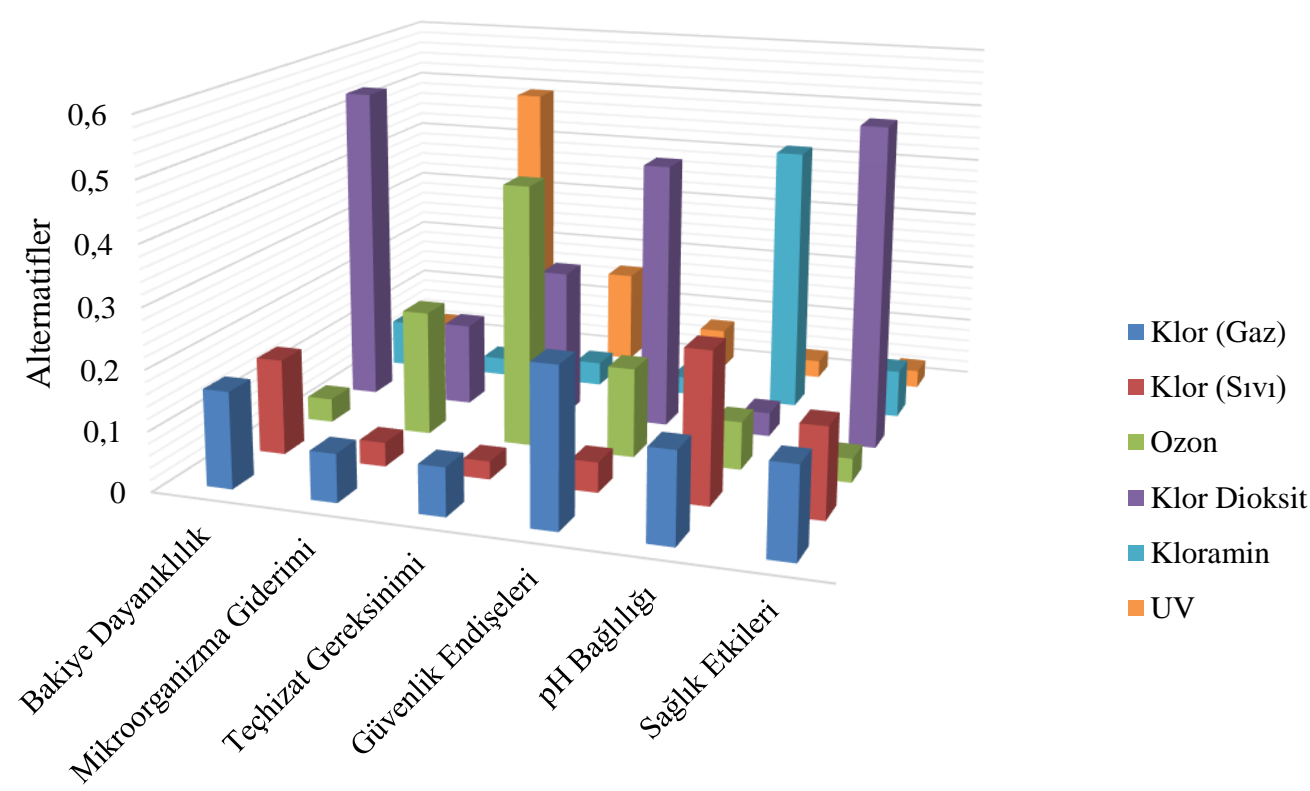

Alt Kriterler

Şekil 2:

Alt Kriterler ve Alternatifler Arasındaki İlişki

Şekil 2 Çok Kriterli Karar Verme Metodu için seçilen alternatiflerin ve alt kriterlerin birbirine göre durumlarını göstermektedir. Grafiğin dikey ekseninde alternatifler, yatay ekseninde ise alt kriterler gösterilmektedir. Alt kriterlerden bakiye dayanıklılık incelendiğinde klor dioksitin diğer alternatiflere göre daha yüksek puan aldığ 1 görülmektedir. Benzer şekilde mikroorganizma gideriminde UV, teçhizat gereksiniminde ozon, güvenlik endişeleri incelendiğinde klor dioksit, pH bağlılığına bakıldığında kloramin ve sağlık etkileri açısından da klor dioksit ön plana çıkmaktadır. 
İncelenen kriterler ve uzman görüşleri neticesinde en yüksek bakiye dayanıklılığa sahip dezenfektan AHS tekniğine göre klor dioksit $(0,54)$ olarak tespit edilmiştir. Klor dioksit, klora kıyasla çok daha etkili bir dezenfektandır ancak maliyet, patlama tehlikesi ve özellikle oluşturduğu yan ürünlerin diyaliz hastaları üzerindeki olumsuz etkilerinden dolayı daha az tercih edilmesi söz konusudur (Lenntech, 2020). AHS tekniği ile elde edilen sonuçlara göre en yüksek mikroorganizma giderimi UV $(0,49)$ ile sağlanmaktadır. İçme suyu arıtımında kullanılan dezenfektanlar virüs, mikroorganizma ya da bakterimi gideriminde seçici özellik gösterirken, UV su kaynaklarında bulunan tüm istenmeyen patojenler üzerinde öldürücü etkisi olduğu bilinmektedir (Hijnen ve diğ., 2006). AHS yöntemine göre en fazla teçhizat gereksinimi ozon $(0,44)$ kullanıldığında ortaya çıkmaktadır. Ozon çalışmalarında karşılaşılan olumsuz yönlerin başında yüksek uçuculuğa sahip olması, tehlikeli bir dezenfektan olması ve teçhizat gereksiniminin fazla olmasıdır (Gomes ve diğ., 2019). Güvenlik endişeleri göz önüne alındığında en fazla risk klor dioksit $(0,45)$ kullanımında ortaya çıkmaktadır. Klor dioksitin yanıcı ve patlayıcı özellikleri daha önce rapor edilmiştir (Dong ve diğ., 2017). Bu durum klor dioksitin bakiye dayanıklılık ile sağladığı avantaja olumsuz bir yaklaşım oluşturmaktadır. Klor dioksit kullanımına bağlı yan ürün oluşumu ve halk sağlığı üzerindeki olumsuz etkileri birçok çalışmada vurgulanmıştır. Klor dioksit kullanımına bağlı olarak oluşan yan ürünlerin su arıtma tesislerinde, rezervuarlarda ve dağıtım sistemlerinde oluştuğu bilinmektedir (Al-Otoum ve diğ., 2016). Uygulanan AHS tekniğine göre alternatifler arasında en fazla $\mathrm{pH}$ bağlılığına sahip dezenfektan kloramin $(0,45)$ olmuştur.

\subsection{TOPSIS Bulguları}

Çalışmanın ikinci aşaması olan TOPSIS yöntemi genel olarak sekiz aşamadan oluşmaktadır. İlk yapılması gereken kriterlerin ve alternatiflerin belirlenmesidir. Çalışma kapsamında TOPSIS, AHS'nin devamı niteliğinde olduğu için kriterler ve alternatifler aynıdır. Bu çalışmada kriter ağırlıkları 1-9 arası puanlama yöntemine göre değerlendirilmiştir. Burada (1) en kötü durumu (9) ise en iyi durumu temsil etmektedir. TOPSIS yöntemi için kriter ağırlıklarını belirlemeye yönelik kesin bir yöntem söz konusu değildir. 1-9 arası puanlama yöntemi yerine AHS, Step-wise Weight Assesment Ratio Analysis (SWARA), ENTROPI ya da farklı puanlama ölçekleri de tercih edilebilir (Özbek, 2018). Çalışmada uygulanan 1-9 arası puanlama yöntemi için uzman görüşleri değerlendirilmiştir. TOPSIS yönteminde kullanılan kriter ağırlıkları, Tablo 4 'te gösterilmektedir.

Tablo 4. Kriter Ăğırlıkları

\begin{tabular}{|c|c|c|c|c|c|c|}
\hline & \multicolumn{7}{|c|}{ Kriter Ağırlıkları } \\
\cline { 2 - 7 } & $\begin{array}{c}\text { Bakiye } \\
\text { Dayanıklı1ık }\end{array}$ & $\begin{array}{c}\text { Mikroorganizma } \\
\text { Giderimi }\end{array}$ & $\begin{array}{c}\text { Teçhizat } \\
\text { Gereksinimi }\end{array}$ & $\begin{array}{c}\text { Güvenlik } \\
\text { Endişeleri }\end{array}$ & $\begin{array}{c}\mathrm{pH} \\
\text { Bağımlılı̆̆ }\end{array}$ & $\begin{array}{c}\text { Sağlık } \\
\text { Etkileri }\end{array}$ \\
\hline Puan & 5 & 7 & 6 & 5 & 6 & 5 \\
\hline Wj & 0,14 & 0,20 & 0,17 & 0,14 & 0,17 & 0,14 \\
\hline
\end{tabular}

TOPSIS yönteminin 2. aşaması karar matrisinin oluşturulmasıdır. Burada karar matrisi AHS tekniği ile elde edilen verilerden oluşmakta ve satırlarında alternatiflerin, sütunlarında ise kriterlerin bulunduğu $m * n$ boyutlu bir matristir. Karar matrisinin işlem görüntüsü Denklem 10 'da gösterilmektedir. TOPSIS yönteminde kullanılan başlangıç karar matrisi ise, Tablo 5'te gösterilmektedir.

$$
A=\left[\begin{array}{ccc}
a_{11} & \cdots & a_{1 n} \\
\vdots & \ddots & \vdots \\
a_{m 1} & \cdots & a_{m n}
\end{array}\right]
$$


Özgür C.: Düşük Bromür ve Orgn. Madde İçer. Su Kayn. İçin Ön Dezenf. Seçim. Çok Ölç. Karar Metotlar.

Tablo 5. Başlangıç Karar Matrisi

\begin{tabular}{|c|c|c|c|c|c|c|}
\hline & \multicolumn{7}{|c|}{ Başlangıç Karar Matrisi } \\
\cline { 2 - 7 } & $\begin{array}{c}\text { Bakiye } \\
\text { Dayanıklı1 }\end{array}$ & $\begin{array}{c}\text { Mikroorganizma } \\
\text { Giderimi }\end{array}$ & $\begin{array}{c}\text { Teçhizat } \\
\text { Gereksinimi }\end{array}$ & $\begin{array}{c}\text { Güvenlik } \\
\text { Endişeleri }\end{array}$ & $\begin{array}{c}\text { pH } \\
\text { Bağımlılı̆̆1 }\end{array}$ & $\begin{array}{c}\text { Sağlık } \\
\text { Etkileri }\end{array}$ \\
\hline Klor (Gaz) & 0,16 & 0,08 & 0,08 & 0,26 & 0,15 & 0,15 \\
\hline Klor (Sıv1) & 0,16 & 0,04 & 0,03 & 0,05 & 0,25 & 0,15 \\
\hline Ozon & 0,04 & 0,21 & 0,44 & 0,15 & 0,08 & 0,04 \\
\hline Klor Dioksit & 0,54 & 0,14 & 0,25 & 0,45 & 0,04 & 0,54 \\
\hline Kloramin & 0,08 & 0,03 & 0,04 & 0,03 & 0,45 & 0,08 \\
\hline UV & 0,03 & 0,49 & 0,16 & 0,07 & 0,03 & 0,03 \\
\hline KARESI & 0,35 & 0,32 & 0,29 & 0,30 & 0,30 & 0,35 \\
\hline KAREKÖK & 0,59 & 0,56 & 0,54 & 0,55 & 0,54 & 0,59 \\
\hline
\end{tabular}

Yöntemin 3. aşaması karar matrisinde oluşan verilerin normalizasyon işlemidir. Normalizasyon işlemine ait işlem, Denklem 11 'de, normalizasyon matrisinin görüntüsü, Denklem 12 'de, Normalize edilmiş matris ise, Tablo 6' da gösterilmektedir.

$$
\begin{gathered}
r_{i j}=\frac{a_{i j}}{\sqrt{\sum_{i=1}^{m} a_{i j}^{2}}} \quad i=\overline{1, m} ; \quad j=\overline{1, n} \\
R=\left[\begin{array}{ccc}
r_{11} & \cdots & r_{1 n} \\
\vdots & \ddots & \vdots \\
r_{m 1} & \cdots & r_{m n}
\end{array}\right]
\end{gathered}
$$

Tablo 6. Ağırlıklandırılmış Normalize Edilmiş Matris

\begin{tabular}{|c|c|c|c|c|c|c|}
\hline & \multicolumn{7}{|c|}{ Normalleştirilmiş Matris } \\
\cline { 2 - 7 } & $\begin{array}{c}\text { Bakiye } \\
\text { Dayanıklı1k }\end{array}$ & $\begin{array}{c}\text { Mikroorganizma } \\
\text { Giderimi }\end{array}$ & $\begin{array}{c}\text { Teçhizat } \\
\text { Gereksinimi }\end{array}$ & $\begin{array}{c}\text { Güvenlik } \\
\text { Endişeleri }\end{array}$ & $\begin{array}{c}\mathrm{pH} \\
\text { Bağımlılığ }\end{array}$ & $\begin{array}{c}\text { Sağlık } \\
\text { Etkileri }\end{array}$ \\
\hline Klor (Gaz) & 0,268 & 0,144 & 0,147 & 0,473 & 0,268 & 0,262 \\
\hline Klor (Sıv1) & 0,268 & 0,075 & 0,047 & 0,087 & 0,467 & 0,252 \\
\hline Ozon & 0,060 & 0,380 & 0,820 & 0,272 & 0,149 & 0,072 \\
\hline Klor Dioksit & 0,912 & 0,242 & 0,463 & 0,822 & 0,082 & 0,917 \\
\hline Kloramin & 0,137 & 0,056 & 0,080 & 0,049 & 0,824 & 0,138 \\
\hline UV & 0,058 & 0,876 & 0,288 & 0,130 & 0,047 & 0,051 \\
\hline
\end{tabular}

Yöntemin 4. aşamasında ağırlıklı karar matrisi oluşturulmalıdır. Bu aşamada her bir kriter için tespit edilmiş ağırlıkları $\left(w_{j}\right)$ ile normalize edilmiş karar matrisindeki kriter değerleri 
çarpılmaktadır. Burada önemli olan bir diğer husus ağırlıkların toplamının 1 olması gerektiğidir. İşleme dair hesap matrisi, Denklem 13'te, işlem sonucu elde edilen ağırlıklı karar matrisi ise, Tablo 7'de gösterilmektedir.

$$
V=\left[\begin{array}{ccc}
w_{1} r_{11} & \cdots & w_{n} r_{1 n} \\
\vdots & \ddots & \vdots \\
w_{1} r_{m 1} & \cdots & w_{n} r_{m n}
\end{array}\right]=\left[\begin{array}{ccc}
v_{11} & \cdots & v_{1 n} \\
\vdots & \ddots & \vdots \\
v_{m 1} & \cdots & v_{m n}
\end{array}\right]
$$

Tablo 7. Ağırlıkı Karar Matrisi

\begin{tabular}{|c|c|c|c|c|c|c|}
\hline & \multicolumn{6}{|c|}{ Ağırlıkı Karar Matrisi } \\
\cline { 2 - 7 } & $\begin{array}{c}\text { Bakiye } \\
\text { Dayanılı1ık }\end{array}$ & $\begin{array}{c}\text { Mikroorganizma } \\
\text { Giderimi }\end{array}$ & $\begin{array}{c}\text { Teçhizat } \\
\text { Gereksinimi }\end{array}$ & $\begin{array}{c}\text { Güvenlik } \\
\text { Endişeleri }\end{array}$ & $\begin{array}{c}\mathrm{pH} \\
\text { Bağımlı̆ı̆ } 1\end{array}$ & $\begin{array}{c}\text { Sağlık } \\
\text { Etkileri }\end{array}$ \\
\hline Klor (Gaz) & 0,039 & 0,030 & 0,026 & 0,070 & 0,047 & 0,039 \\
\hline Klor (Sıv1) & 0,039 & 0,015 & 0,008 & 0,013 & 0,082 & 0,037 \\
\hline Ozon & 0,009 & 0,078 & 0,145 & 0,040 & 0,026 & 0,011 \\
\hline Klor Dioksit & 0,134 & 0,050 & 0,082 & 0,121 & 0,014 & 0,135 \\
\hline Kloramin & 0,020 & 0,011 & 0,014 & 0,007 & 0,145 & 0,020 \\
\hline UV & 0,009 & 0,180 & 0,051 & 0,019 & 0,008 & 0,007 \\
\hline
\end{tabular}

TOPSIS yönteminin 5. aşamasında ideal ve negatif çözümler hesaplanmalıdır. Burada Pozitif İdeal Çözüm (PİÇ) ve Negatif İdeal Çözüm (NİÇ) hesaplanmalıdır. Her bir kriter için en yüksek ve en düşük değerler bu aşamada hesaplanmaktadır. İşleme ait eşitlikler, Denklem 14 ve Denklem 15 'te gösterilirken, İdeal ve Negatif Çözüm Değerleri Kümesi, Tablo 8'de gösterilmektedir.

$$
\begin{aligned}
& A^{*}=\left\{\left(\frac{\max _{i j}}{j} \in J\right),\left(\frac{\operatorname{minv}_{i j}}{j} \in J^{\prime}\right)\right\},\left(A^{*}=\left\{v_{1}^{*}, v_{2}^{*}, \ldots, v_{n}^{*}\right\}\right) \\
& A^{-}=\left\{\left(\frac{\operatorname{minv}_{i j}}{j} \in J\right),\left(\frac{\max _{i j}}{j} \in J^{\prime}\right)\right\},\left(A^{-}=\left\{v_{1}^{-}, v_{2}^{-}, \ldots, v_{n}^{-}\right\}\right)
\end{aligned}
$$

Tablo 8. İdeal ve Negatif Çözüm Değerler

\begin{tabular}{|c|c|c|c|c|c|c|}
\hline & \multicolumn{7}{|c|}{ İdeal ve Negatif Çözüm Kümesi } \\
\hline PİÇ & 0,0086 & 0,0114 & 0,1447 & 0,1209 & 0,0084 & 0,1349 \\
\hline NİÇ & 0,1341 & 0,1803 & 0,1447 & 0,1209 & 0,1454 & 0,1349 \\
\hline
\end{tabular}

TOPSIS yönteminin 6. aşamasında ideal çözüme en yakın uzaklık ile en uzak uzaklık tespit edilmektedir. Bu aşamada kriterlerin en geniş aralığı gözler önüne serilmektedir. Bu aşamaya ait formüller, Denklem 16 ve Denklem 17'de gösterilmektedir. En yakın uzaklık, Tablo 9'da, en uzak uzaklık ise, Tablo 10' da gösterilmektedir.

$$
S_{i}^{*}=\sqrt{\sum_{j=1}^{n}\left(v_{i j}-v_{j}^{*}\right)^{2}}
$$


Özgür C.: Düşük Bromür ve Orgn. Madde İçer. Su Kayn. İçin Ön Dezenf. Seçim. Çok Ölç. Karar Metotlar.

$$
S_{i}^{-}=\sqrt{\sum_{j=1}^{n}\left(v_{i j}-v_{j}^{-}\right)^{2}}
$$

Tablo 9. Pozitif İdeal Uzaklıkların Hesaplanması

\begin{tabular}{|c|c|c|c|c|c|c|}
\hline & \multicolumn{7}{|c|}{ Pozitif Ayırım Ölçütleri } \\
\cline { 2 - 7 } & $\begin{array}{c}\text { Bakiye } \\
\text { Dayanıklılı }\end{array}$ & $\begin{array}{c}\text { Mikroorganizma } \\
\text { Giderimi }\end{array}$ & $\begin{array}{c}\text { Teçhizat } \\
\text { Gereksinimi }\end{array}$ & $\begin{array}{c}\text { Güvenlik } \\
\text { Endişeleri }\end{array}$ & $\begin{array}{c}\mathrm{pH} \\
\text { Bağımlılı̆̆ }\end{array}$ & $\begin{array}{c}\text { Sağlık } \\
\text { Etkileri }\end{array}$ \\
\hline$S_{i}^{+1}$ & 0,0947 & 0,0333 & 1,4127 & 0,2640 & 0,1521 & 0,9271 \\
\hline$S_{i}^{+2}$ & 0,0947 & 0,0016 & 1,8599 & 1,1698 & 0,5485 & 0,9569 \\
\hline$S_{i}^{+3}$ & 0,0000 & 0,4476 & 0,0000 & 0,6538 & 0,0320 & 1,5423 \\
\hline$S_{i}^{+4}$ & 1,5747 & 0,1472 & 0,3978 & 0,0000 & 0,0037 & 0,0000 \\
\hline$S_{i}^{+5}$ & 0,0135 & 0,0000 & 1,7078 & 1,2938 & 1,8766 & 1,3113 \\
\hline$S_{i}^{+6}$ & 0,0000 & 2,8527 & 0,8812 & 1,0360 & 0,0000 & 1,6221 \\
\hline
\end{tabular}

Tablo 10. Negatif İdeal Uzaklıkların Hesaplanması

\begin{tabular}{|c|c|c|c|c|c|c|}
\hline & \multicolumn{7}{|c|}{ Negatif Karar Matrisi } \\
\hline & $\begin{array}{c}\text { Bakiye } \\
\text { Dayanıklılı }\end{array}$ & $\begin{array}{c}\text { Mikroorganizma } \\
\text { Giderimi }\end{array}$ & $\begin{array}{c}\text { Teçhizat } \\
\text { Gereksinimi }\end{array}$ & $\begin{array}{c}\text { Güvenlik } \\
\text { Endişeleri }\end{array}$ & $\begin{array}{c}\mathrm{pH} \\
\text { Bağımlılı̆̆1 }\end{array}$ & $\begin{array}{c}\text { Sağlık } \\
\text { Etkileri }\end{array}$ \\
\hline$S_{i}^{-1}$ & 0,8969 & 2,2700 & 1,4127 & 0,2640 & 0,9603 & 0,9271 \\
\hline$S_{i}^{-2}$ & 0,8969 & 2,7195 & 1,8599 & 1,1698 & 0,3960 & 0,9569 \\
\hline$S_{i}^{-3}$ & 1,5694 & 1,0404 & 0,0000 & 0,6538 & 1,4183 & 1,5423 \\
\hline$S_{i}^{-4}$ & 0,0000 & 1,7038 & 0,3978 & 0,0000 & 1,7130 & 0,0000 \\
\hline$S_{i}^{-5}$ & 1,2969 & 2,8527 & 1,7078 & 1,2938 & 0,0000 & 1,3113 \\
\hline$S_{i}^{-6}$ & 1,5747 & 0,0000 & 0,8812 & 1,0360 & 1,8766 & 1,6221 \\
\hline
\end{tabular}

Yöntemin 7. aşamasında her bir kriterin ideal çözüme göreli yakınlığı hesaplanmaktadır. Göreli yakınlık hesaplanırken 6. aşamada elde edilen bulgular kullanılmaktadır. Göreli yakınlık $C_{i}^{*}$ ile gösterilmektedir. $C_{i}^{*} 0-1$ aralığında değer almaktadır. 1'e yakın değer alması pozitif ideal çözüme yakın olduğunu, 0'a yakın değer alması ise negatif ideal çözüme yakın olduğunu göstermektedir. İdeal çözüme göre yakınlık, Denklem 18'deki işleme göre gerçekleştirilmektedir.

$$
C_{i}^{*}=\frac{S_{i}^{*}}{S_{i}^{-}+S_{i}^{*}}
$$


Tekniğin son aşamasında ise $C_{i}^{*}$ 'a göre alternatiflerin sıralaması gerçekleştirilir. Tablo 11'de TOPSIS yöntemine göre alternatiflerin sıralaması, Şekil 3'te ise TOPSIS yöntemine göre alternatiflerin tercih sıralaması gösterilmektedir.

Tablo 11. Sonuç Tablosu

\begin{tabular}{|c|c|c|c|c|c|c|c|}
\hline \multicolumn{7}{|c|}{ Ayırım Ölçütlerinin Hesaplanması } \\
\hline \multicolumn{2}{|c|}{$S_{i}^{*}$} & \multicolumn{2}{|c|}{$S_{i}^{-}$} & \multicolumn{2}{|c|}{$C_{i}^{*}$} & \multicolumn{2}{c|}{ Srralama } \\
\hline$S_{i}^{+1}$ & 1,6982 & $S_{i}^{-1}$ & 2,5944 & $C_{i}^{1}$ & 0,6044 & Klor (Gaz) & 1 \\
\hline$S_{i}^{+2}$ & 2,1521 & $S_{i}^{-2}$ & 2,8283 & $C_{i}^{2}$ & 0,5679 & Klor (Sıv1) & 4 \\
\hline$S_{i}^{+3}$ & 1,6357 & $S_{i}^{-3}$ & 2,4948 & $C_{i}^{3}$ & 0,6040 & Ozon & 2 \\
\hline$S_{i}^{+4}$ & 1,4572 & $S_{i}^{-4}$ & 1,9531 & $C_{i}^{4}$ & 0,5727 & Klor Dioksit & 3 \\
\hline$S_{i}^{+5}$ & 2,4906 & $S_{i}^{-5}$ & 2,9090 & $C_{i}^{5}$ & 0,5388 & Kloramin & 5 \\
\hline$S_{i}^{+6}$ & 2,5283 & $S_{i}^{-6}$ & 2,6440 & $C_{i}^{6}$ & 0,5112 & UV & 6 \\
\hline
\end{tabular}

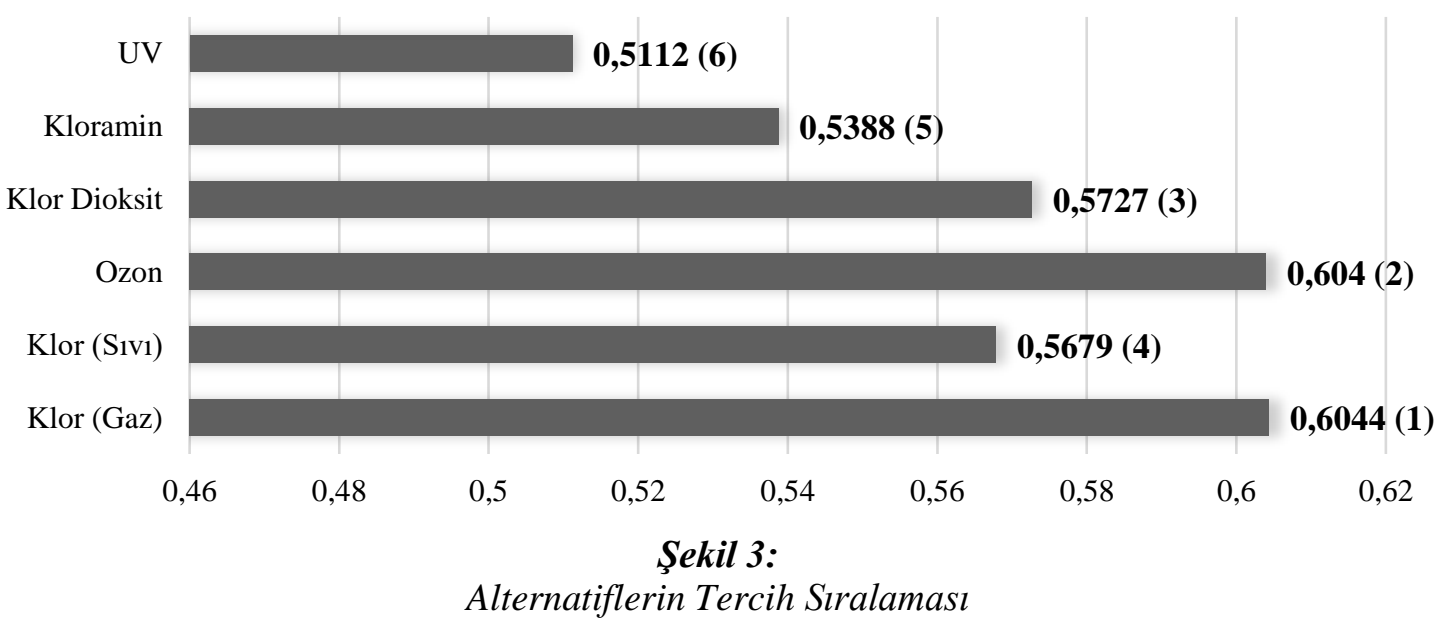

TOPSIS hesaplamaları sonucunda düşük TOK ve düşük bromür içeren su kaynaklarında ön dezenfektan olarak kullanılabilecek dezenfektanlar arasında en iyi alternatif olarak klor (gaz) ortaya çıkmaktadır. Diğer alternatifler ise sırasıyla ozon, klor dioksit, klor (sıvı), kloramin ve UV olarak belirlenmiştir. İdeal çözüme göre yapılan sıralamada dezenfektanlar 0,51-0,60 aralığında değerler almıştır. Bu değerler farklı uzman görüşleri ile farklı sonuçlanabilir. İşletmeler açısından gaz klor kullanımı en yaygın dezenfektan türüdür (Kumari ve Gupta, 2015). Sıv1 klor ile karşılaştırıldığında gaz klor çok daha ucuzdur (Moghadam ve Dore, 2019). Ancak sıvı klorun tehlike yaratma potansiyelinin düşük olması ve çok daha az ekipmanla tatbik edilmesi önemli bir tercih sebebidir. İkinci alternatif olarak belirlenen ozon da oldukça patlayıcı ve yüksek bromür konsantrasyonuna sahip sularda bromlu DYÜ türlerinin oluşmasına sebep olmaktadır ancak düşük bromür konsantrasyonuna sahip sularda en etkili dezenfektanlardan biridir (Neale ve Leusch, 2019). Klor dioksitin oksitleme özelliği gaz klorla kıyaslandığında 2,5 kat daha fazladır (Ben ve diğ., 2017). Ancak klor dioksitin depolanamaması, ortam şartlarından etkilenmesi ve patlayıcı özelliği klor dioksiti ilk tercih edilen dezenfektanlar arasına almamaktadır. Kloramin hazırlanırken amonyak kullanılması tehlikeli durumların ortaya çıkmasına neden olurken aynı zamanda pH'a bağlı olarak hazırlanması da ilave maliyet gerektirmektedir. Ayrıca kloramin, 
diğer dezenfektanlara kıyasla dezenfeksiyon etkinliği çok yüksek olmayan bir kimyasaldır (Yan ve diğ., 2018).

$\mathrm{Bu}$ çalışmada elde edilen sonuçlara göre düşük organik madde ve düşük bromür konsantrasyonuna sahip su kaynakları için ön dezenfektan seçiminde işletme parametreleri çok önemlidir. Uzman görüşlerine göre değerlendirilen AHS ve TOPSIS tekniklerine göre her bir alternatifin kendine özgü avantaj ve dezavantajları mevcuttur. Seçim noktasında en önemli kriterler işletme açısından teçhizat gereksinimi ve güvenlik endişeleri olmalıdır. Toplum sağlı̆̆ açısından bakıldığından ise bakiye dayanıklılık ve sağlık etkileri ön plana çıkarılmalıdır.

\section{SONUÇLAR}

Yürütülen bu çalışmada toplum sağlığı için büyük önem taşıyan içme suyu arıtma tesislerinde uygulanabilecek "en uygun ön dezenfektan seçiminde", Çok Ölçütlü Karar Verme Yöntemleri kullanılmıştır. En uygun ön dezenfektanı belirlemek adına AHS ve TOPSIS yöntemleri kullanılmıştır. Çok Ölçütlü Karar Verme Metotları bilgi birikiminin ve deneyimin yeterli olduğu tüm sektörlerde kolaylıkla ve güvenilir bir şekilde kullanılabilmektedir. İçme suyu arıtma tesislerinde uygulanan proseslerin birçoğu da yıllar içerisinde kabul görmüş metotlardır. Ancak yine de yeni bir tesis tasarlanırken pilot ölçekte testler gerçekleştirilmektedir. $\mathrm{Bu}$ testler, işletmeler açısından hem maddi kayıplara hem de zaman kaybına yol açmaktadır. Çok Ölçütlü Karar Verme Metotları kullanılarak işletmelerde meydana gelebilecek kayıların önüne geçilebilir. $\mathrm{Bu}$ bağlamda, bu çalışmanın Çevre Mühendisliği alanında çalışmalar yapan araştırmacılara yeni fikirler sunması hedeflenmiştir.

Çalışma kapsamında öncelikle ülkemizin su kaynakları hakkında bir literatür taraması gerçekleştirilmiştir. Uzman görüşleri alınarak su kaynaklarında ön dezenfektanların seçilmesine neden olabilecek kriterlerin neler olabileceği belirlenmiștir. Daha sonra ülkemizin sularının geneline uygulanabilecek dezenfektanlar, alternatifler olarak seçilmiştir. Çalışma kapsamında AHS metodu ile elde edilen sonuçlara göre bakiye dayanıklılı̆̆ı en yüksek çıkan dezenfektan klor dioksit, mikroorganizma giderimi en yüksek olan dezenfektan UV, teçhizat gereksinimi en fazla olan dezenfektan ozon, güvenlik endişeleri en yüksek olan dezenfektan klor dioksit, $\mathrm{pH}$ bağ l1lığ en fazla olan dezenfektan kloramin ve sağlı etkileri en fazla çıkan dezenfektan ise klor dioksit olarak tespit edilmiştir. AHS tekniği ile elde edilen alternatif ağırlıkları TOPSIS tekniğinde kullanılmıştır. TOPSIS tekniği ile elde edilen sonuçlara göre ise, klor (gaz) ve ozonun tercih edilme durumları $\% 18$, klor dioksitin tercih edilme durumu \%17, klor (sıv1) ve kloraminin tercih edilme durumu \%16, UV'nin tercih edilme durumu ise \%15 olarak belirlenmiştir. Sonuçta elde edilen verilere göre her bir alternatif ön dezenfektan olarak seçilebilir şekilde birbirine yakın sonuçlar vermiştir. UV kullanımının mikroorganizma giderimi oldukça yüksektir ancak bakiye bırakma özelliği de aynı derecede çok düşüktür. Ön dezenfektan kullanımının temel amaçlarından biri de son dezenfektan kullanımını azaltmak olduğu için UV son tercih olmaktadır. Kloraminin pH bağlılığı tercih sebebi olmasını düşürmektedir. Klor dioksitin en yüksek bakiye dayanıklılığa sahip olması çok iyi bir avantajdır ancak aynı şekilde güvenlik endişelerinin ve sağlık etkilerinin olumsuz bir şekilde yüksek olması, tercih edilmemesine neden olmaktadır. Ozon düşük TOK ve düşük bromürlü su kaynaklarında çok etkin kullanılabilecek bir dezenfektandır. Ancak gaz klorun teçhizat gereksinimi, güvenlik endişeleri, $\mathrm{pH}$ bağl1lı̆̆ ve sağlık etkileri gibi olumsuz kriterlerde yüksek puan almaması ve bakiye dayanıklılığın yüksek olması, klor gazının en iyi ön dezenfektan olarak seçilmesine neden olmaktadır. 


\section{KAYNAKLAR}

1. Aieta, E. M., ve Berg, J. D. (1986) A Review of Chlorine Dioxide in Drinking Water Treatment, Journal-American Water Works Association, 78(6), 62-72. https://doi.org/10.1002/j.1551-8833.1986.tb05766.x.

2. Al-Otoum, F., Al-Ghouti, M. A., Ahmed, T. A., Abu-Dieyeh, M. ve Ali, M. (2016) Disinfection by-products of chlorine dioxide (chlorite, chlorate, and trihalomethanes): Occurrence in drinking water in Qatar, Chemosphere, 164, 649-656. https://doi.org/10.1016/j.chemosphere.2016.09.008

3. Ao, X., Chen, Z., Li, S., Li, C., Lu, Z. ve Sun, W. (2020) The impact of UV treatment on microbial control and DBPs formation in full-scale drinking water systems in northern China, Journal of Environmental Sciences, 87, 398 - 410. https://doi.org/10.1016/j.jes.2019.08.003

4. Ates, N., Kaplan, S. S., Sahinkaya, E., Kitis, M., Dilek, F. B. ve Yetis, U. (2007) Occurrence of disinfection by-products in low DOC surface waters in Turkey, Journal of Hazardous Materials, 142, 526-534. doi: 10.1016/j.jhazmat.2006.08.076.

5. Atıcı, K. B. ve Ulucan, A. (2009) Enerji Projelerinin Değerlendirilmesi Sürecinde Çok Kriterli Karar Verme Yaklaşımları ve Türkiye Uygulamaları, H.Ü. İktisadi ve İdari Bilimler Fakültesi Dergisi, 27(1), 161-186.

6. Ben, W., Shi, Y., Li, W., Zhang, Y. ve Qiang, Z. (2017) Oxidation of sulfonamide antibiotics by chlorine dioxide in water: Kinetics and reaction pathways, Chemical Engineering Journal, 327, 743-750. https://doi.org/10.1016/j.cej.2017.06.157

7. Bertolini, M. ve Bevilacqua, M. (2006) A Combined Goal Programming-AHP Approach to Maintenance Selection Problem, Reliability Engineering and System Safety, 91, 839-848. https://doi.org/10.1016/j.ress.2005.08.006

8. Bond, T., Templeton, M. R., Kamal, N. H. M., Graham, N. ve Kanda R. (2015) Nitrogenous Disinfection Byproducts in English Drinking Water Supply Systems: Occurrence, Bromine Substitution and Correlation Analysis, Water Research, 85, 85-94. https://doi.org/10.1016/j.watres.2015.08.015

9. Bouchard, C., Abi-Zeid, I., Beauchamp, N., Lamontagne, L., Desrosiers, J. ve Rodriguez, M. (2010) Multicriteria decision analysis for the selection of a small drinking water treatment system, Journal of Water Supply: Research and Technology-AQUA | 59.4. https://doi.org/10.2166/aqua.2010.071

10. Brodowska, A.J., Nowak, A. ve Smigielski, K. (2018) Ozone in the food industry: Principles of ozone treatment, mechanisms of action, and applications: An overview, Critical Reviews in Food Science and Nutrition, 58(13), 2176-2201. DOI: 10.1080/10408398.2017.1308313

11. Butchart-Kuhlmann, D., Kralisch, S., Fleischer M. ve Meinghardt, M. (2018) Multicriteria decision analysis framework for hydrological decision support using environmental flow components, Ecological Indicators 93, 470-480. https://doi.org/10.1016/j.ecolind.2018.04.057

12. Chang, J. C. H., Ossoff, S. F., Lobe, D. C., Dorfman, M. H., Dumais, C. M., Qualls, R. G. ve Johnson, J. D. (1985) UV Inactivation of Pathogenic and Indicator Microorganisms, Applied And Environmental Microbiology, 1361-1365.

13. Chowdhury, S. (2017) Selection of Municipal Drinking Water Treatment Approach using Multiple Criteria, Encyclopedia of Sustainable Technologies, Volume 4 http://dx.doi.org/10.1016/B978-0-12-409548-9.10527-5 
Özgür C.: Düşük Bromür ve Orgn. Madde İçer. Su Kayn. İçin Ön Dezenf. Seçim. Çok Ölç. Karar Metotlar.

14. Chung, E. S. ve Lee, K. S. (2009) Prioritization of water management for sustainability using hydrologic simulation model and multicriteria decision making techniques, Journal of Environmental Management, 90, 1502-1511. https://doi.org/10.1016/j.jenvman.2008.10.008

15. Cortes, C. ve Marcos, R. (2018) Genotoxicity of disinfection byproducts and disinfected waters: A review of recent literatüre, Mutat Res Gen Tox En, 831, 1-12. DOI: 10.1016/j.mrgentox.2018.04.005

16. Demireli, E. (2010) TOPSIS Çok Kriterli Karar Verme Sistemi: Türkiye'deki Kamu Bankaları Üzerine Bir Uygulama, Girişimcilik ve Kalkınma Dergisi (5:1).

17. Dong, J., Zhu, L., Gu, D., Sheng, H., Yan, Ch. ve Wang B. (2017) Theoretical and experimental study on the safety chemistry of separation of oil/water transition layer by oxidation of chlorine dioxide, Bulgarian Chemical Communications, Volume 49, Special Edition K1, (pp. 24 - 28).

18. Emetere, M. E. ve Akinyemi, M. L. (2017) Atmospheric Dynamics of Air Pollution Dispersion and Sustainable Environment in Jos-Nigeria, Journal of Urban and Environmental Engineering, v.11, n.1, p.51-57. DOI: 10.4090/juee.2017.v11n1.051057

19. Ersan, M. S., Liu, C., Amy, G. ve Karanfil, T. (2019) The interplay between natural organic matter and bromide on bromine substitution, Science of the Total Environment 646, 1172 1181. https://doi.org/10.1016/j.scitotenv.2018.07.384

20. Esquivel, J. M., Morales, G. P. ve Esteller, M. V. (2015), Groundwater Monitoring Network Design Using GIS and Multicriteria Analysis, Water Resour Manage 29:3175-3194. https://doi.org/10.1007/s11269-015-0989-8

21. Gan, X., Karanfil, T., Kaplan Bekaroğlu, S. S. ve Shan, J. (2013) The control of N-DBP and C-DBP precursors with MIEX®, Water Research, 47, 1344-1352. https://doi.org/10.1016/j.watres.2012.11.049

22. Gomes, J., Matos, A., Gmurek, M., Quinta-Ferreira, R. M. ve Martins, R. C. (2019), Ozone and Photocatalytic Processes for Pathogens Removal from Water: A Review, Catalysts, 9, 46. doi:10.3390/catal9010046.

23. Hao, R., Zhang, Y., Du, T., Yang, L., Adeleye, A. S. ve Li Y. (2017) Effect of water chemistry on disinfection by-product formation in the complex surface water system, Chemosphere, 172, 384-391. https://doi.org/10.1016/j.chemosphere.2016.12.034

24. Hijnen, W. A. M., Beerendonk, E. F. ve Medema, G. J. (2006) Inactivation credit of UV radiation for viruses, bacteria and protozoan (oo)cysts in water: A review, Water Research, 40, 3 - 22. https://doi.org/10.1016/j.watres.2005.10.030

25. Huang, J., Wang, L., Ren, N., Ma, F. ve Juli, T. (1996), Disinfection Effect of Chlorine Dioxide on Bacteria in Water, Wat. Res. Vol. 31, No. 3, pp. 607-613. https://doi.org/10.1016/S0043-1354(96)00275-8

26. https://www.lenntech.com/processes/disinfection/chemical/disinfectants-chlorinedioxide.htm, Erişim Tarihi: 10.07.2020, Konu: Dezenfektan-Klor Dioksit.

27. http://www.dsi.gov.tr/toprak-ve-su-kaynaklari, Erişim Tarihi: 10.07.2020, Konu: Toprak ve Su Kaynakları

28. Ignatev, A. ve Tuhkanen, T. (2019), Step-by-step analysis of drinking water treatment trains using size-exclusion chromatography to fingerprint and track protein-like and humic/ fulviclike fractions of dissolved organic matter, Environ. Sci.: Water Res. Technol, 5, 1568. DOI: 10.1039/C9EW00340A 
29. İTASHY, (2005). İnsani Tüketim Amaçlı Sular Hakkında Yönetmelik, Sağlık Bakanlığ1, Ankara.

30. Jones, C. H., Meyer, J., Cornejo, P. K., Hogrewe, W., Seidel, C. J. ve Cook, S. M. (2019) A new framework for small drinking water plant sustainability support and decision-making, $\begin{array}{llllll}\text { Science of the Total Environment, } & 6953899 .\end{array}$ https://doi.org/10.1016/j.scitotenv.2019.133899

31. Karahalios, H. (2017) The application of the AHP-TOPSIS for evaluating ballast water treatment systems by ship operators, Transportation Research Part D 52, 172-184. https://doi.org/10.1016/j.trd.2017.03.001

32. Kumari, M. ve Gupta, S. K. (2015) Modeling of trihalomethanes (THMs) in drinking water supplies: a case study of eastern part of India, Environ Sci Pollut Res, 22, 12615-12623. https://doi.org/10.1007/s11356-015-4553-0

33. Lin, J., Chen, X., Zhu, A., Hong, H., Liang, Y., Sun, H., Lin, H. ve Chen, J. (2018) Regression models evaluating THMs, HAAs and HANs formation upon chloramination of source water collected from Yangtze River Delta Region, China, Ecotoxicology and Environmental Safety, 160, 249-256. https://doi.org/10.1016/j.ecoenv.2018.05.038

34. Moghadam, A. K. ve Dore, M. H. I. (2019) The Comparative Disinfection Costs of Municipal Drinking Water Plants in Canada, International Review of Business and Applied Sciences, Volume 1, No. 1.

35. Morais, D. C. ve Almeida, A. T. (2006) Water supply system decision making using multicriteria analysis, Water SA Vol. 32 No:2. DOI: 10.4314/wsa.v32i2.5247

36. Neale, P. A. ve Leusch, F. D. L. (2019) Assessing the role of different dissolved organic carbon and bromide concentrations for disinfection by-product formation using chemical analysis and bioanalysis, Environmental Science and Pollution Research, 26,17100-17109. https://doi.org/10.1007/s11356-019-05017-0

37. Negi, P. ve Jain, K. (2008) Spatial Multicriteria Analysis for Siting Groundwater Polluting Industries, Journal of Environmental Informatics, 12(1), 54-63. DOI: 10.3808/jei.200800124

38. Oğuzhan Yıldız, P. ve Yangılar, F. (2014) Ozon ve Gıda Endüstrisinde Kullanım Alanları, BEÜ, Fen Bilimleri Dergisi, 3(1), 94-101.

39. Okeola, O. G. ve Sule, B. F. (2012) Evaluation of management alternatives for urban water supply system using Multicriteria Decision Analysis, Journal of King Saud University Engineering Sciences, 24, 19-24. https://doi.org/10.1016/j.jksues.2011.07.004

40. Öztürk, E. (2017) İçme Sularından Pentaklorofenol (PCP) Giderimi İçin En İyi Arıtma Alternatiflerinin Çok Ölçütlü Karar Verme Metotları (MCDM) Kullanılarak Belirlenmesi, Karaelmas Fen ve Müh. Derg., 8(1), 373-382. http://dx.doi.org/10.7212\%2Fzkufbd.v8i1.1196

41. Ozturk, E. (2018) Applying analytical decision methods for determination of the best treatment alternative to remove emerging micropollutants from drinking water and wastewater: triclosan example, Environmental Science and Pollution Research, https://doi.org/10.1007/s11356-018-3036-5.

42. Ömürbek, N., Karaatlı, M. ve Yetim, T. (2014) Analitik Hiyerarşi Sürecine Dayalı TOPSIS ve VIKOR Yöntemleri ile ADIM Üniversitelerinin Değerlendirilmesi, Selçuk Üniversitesi Sosyal Bilimler Enstitüsü Dergisi, Dr. Mehmet YILDIZ Özel Sayısı, ss. 189-207.

43. Özbek, A. (2017) Çok Kriterli Karar Verme Yöntemleri ve Excel ile Problem Çözümü, Seçkin Akademik ve Mesleki Yayınlar, Ankara. ISBN: 978-975-02-5513-7. 
Özgür C.: Düşük Bromür ve Orgn. Madde Içer. Su Kayn. İçin Ön Dezenf. Seçim. Çok Ölç. Karar Metotlar.

44. Özcan, A. ve Ömürbek, N. (2020) Bir Demir Çelik İşletmesinin Performansının Çok Kriterli Karar Verme Yöntemleri ile Değerlendirilmesi, IBAD Sosyal Bilimler Dergisi Sayı: 8 Sayfa: 77-98.

45. Özgür, C. (2019) Farklı Su Kaynaklarında ve Şebekelerde Karbonlu ve Azotlu Dezenfeksiyon Yan Ürünlerinin Oluşumu, Doktora Tezi, Süleyman Demirel Üniversitesi, Fen Bilimleri Enstitüsü, Isparta.

46. Richardson, S. D., Thruston, A. D., Rav-Acha, C., Groisman, L., Popilevsky, I., Juraev, O., Glezer, V., Mckague, A. B., Plewa, M. J. ve Wagner, E. D. (2003) Tribromopyrrole, Brominated Acids, and Other Disinfection Byproducts Produced by Disinfection of Drinking Water Rich in Bromide, Environ. Sci. Technol., 37, 3782-3793. https://doi.org/10.1021/es030339w

47. Ridgway, H. F. ve Olson B. H. (1982) Chlorine Resistance Patterns of Bacteria from Two Drinking Water Distribution Systems, Applied and Environmental Microbiology, p. 972-987.

48. Rook, J. J. (1974) Formation of haloforms during chlorination of natural water, Water Treat. Exam, 23, 234-243.

49. Santos, J., Pagsuyoin, S. A., Latayan, J., (2016) A multi-criteria decision analysis framework for evaluating point-of-use water treatment alternatives, Clean Techn Environ Policy, 18, 1263-1279. https://doi.org/10.1007/s10098-015-1066-y

50. Simonovic, S. P. ve Verma, R. (2008) A new methodology for water resources multicriteria decision making under uncertainty, Physics and Chemistry of the Earth, 33, 322-329. https://doi.org/10.1016/j.pce.2008.02.006

51. Song, K., Mohseni, M. ve Taghipour, F. (2016) Application of ultraviolet light-emitting diodes (UV-LEDs) for water disinfection: A review, Water Research, 94, 341-349. https://doi.org/10.1016/j.watres.2016.03.003

52. Sudhakaran, S., Lattemann, S. ve Amy, G. L. (2013) Appropriate drinking water treatment processes for organic micropollutants removal based on experimental and model studies A multi-criteria analysis study, Science of The Total Environment Volume, 442, 478-488. https://doi.org/10.1016/j.scitotenv.2012.09.076

53. Summerfelt, S. T. (2003) Ozonation and UV irridation-an introduction and examples of current applications, Aquacultural Engineering, 28, 21-36. https://doi.org/10.1016/S01448609(02)00069-9

54. Tobiszewski, M. ve Orłowski, A. (2015) Multicriteria decision analysis in ranking of analytical procedures foraldrin determination in water, Journal of Chromatography A, 1387, 116-122. DOI: 10.1016/j.chroma.2015.02.009

55. Toröz, İ. (2015) Su ve Atıksu Mühendisliği-Tasarım Esasları ve Uygulamaları, Nobel Akademik Yayıncılık Eğitim Danışmanlık Tic. LTD. ŞTİ. Ankara.

56. U.S. EPA (1999) Alternative Disinfectants and Oxidants Guidance Manual, U.S. Environmental Protection Agency Publications EPA 815-R-99-014, Washington, D.C.

57. Voukkali, I. ve Zorpas A. A. (2015) Disinfection methods and by-products formation. Desalination and Water Treatment, 56, 1150-1161. DOI: 10.1080/19443994.2014.941010

58. Wallace, B., Purcell, M. ve Furlong, J., (2002) Total organic carbon analysis as a precursor to disinfection byproducts in potable water: Oxidation technique considerations, J. Environ. Monit., 4, 35-42. DOI: 10.1039/b106049j 
59. Wind, Y. ve Saaty, T. L. (1980) Marketing Applications of the Analytic Hierarchy Process, Management Science, 26, 641-658.

60. Xue, C., Wang, Q., Chu, W. ve Templeton, M. R. (2014) The impact of changes in source water quality on trihalomethane and haloacetonitrile formation in chlorinated drinking water, Chemosphere, 117, 251-255. https://doi.org/10.1016/j.chemosphere.2014.06.083

61. Yan, W., Li, J. ve Bai, X. (2016) Comprehensive Assessment and Visualized Monitoring of Urban Drinking Water Quality, Chemometrics and Intelligent Laboratory Systems, doi: 10.1016/j.chemolab.2016.03.026

62. Yan, M., Roccaro, P., Fabbricino, M. ve Korshin, G. (2018) Comparison of the effects of chloramine and chlorine on the aromaticity of dissolved organic matter and yields of disinfection byproducts, Chemosphere, 191, 477-484. https://doi.org/10.1016/j.chemosphere.2017.10.063

63. Yeh, C. H. (2002) A problem-based selection of multi-attribute decision-making methods, Intl. Trans. in Op. Res., 9, 169 \pm 181.

64. Yıldırım, B. F. ve Önder, E. (2018) Operasyonel, Yönetsel ve Stratejik Problemlerin Çözümünde Çok Kriterli Karar Verme Yöntemleri, Dora Yayıncılık, Bursa. ISBN: 978-605247-004-6. 
